\title{
Pengaruh Hukuman Orang Tua terhadap Disiplin Belajar Anak di Pematang Siantar
}

\author{
Dewi Ramadhani Siregar ${ }^{1}$, Elizon Nainggolan ${ }^{2} *$ \\ ${ }^{1,2)}$ Fakultas Ilmu Pendidikan, Universitas Negeri Medan \\ *elizonnainggo06@gmail.com
}

\begin{abstract}
Abstrak
Orang tua masih banyak menyelesaikan permasalahan perilaku anak dengan memberikan hukuman fisik. Penelitian ini bertujuan mengetahui pengaruh pemberian hukuman yang diberikan oleh orang tua terhadap disiplin belajar anak. Jenis penelitian yang digunakan adalah deskriptif kuantitatif dengan melibatkan anak usia 7-15 tahun sebanyak 36 anak usia di kelurahan Tanjung Tongah Kota Pematang siantar. Hasil analisis dengan regresi linier sederhana menunjukkan adanya pengaruh hukuman orang tua terhadap disiplin belajar anak. Jenis hukuman yang diberikan orang tua kepada anak adalah seperti memukul, mencubit dan menampar. Anak-anak di lokasi penelitian ini memiliki disiplin belajar yang cukup baik. Orang tua seharusnya tidak menghukum anak dengan kekerasan, tetapi mengarahkan anak dengan penuh kasih. Untuk para orang tua perlu diberikan pemahaman tentang dampak hukuman terhadap perkembangan anak.
\end{abstract}

Kata Kunci: Hukuman orang tua, disiplin belajar, anak-anak

\section{Abstract}

Parents still solve many problems of child behavior by giving corporal punishment. This study aims to determine the effect of punishment given by parents to the discipline of learning children. The type of research used is descriptive quantitative by involving children aged 7-15 years as many as 36 children aged in the village of Tanjung Tongah Pematang siantar City. The results of analysis with simple linear regression showed the influence of parents' punishment to the discipline of children's learning. Punishment parents give to children, such as hitting, pinching and slapping. The children in this study area have good learning discipline. Parents should not punish the child with violence, but lead the child lovingly. Parents need to be given an understanding of the impact of penalties on child development.

Keywords: parent's punishment, learning discipline, children

\section{PENDAHULUAN}

Hukuman sering sekali dianggap dapat mengatasi permasalahan anak. Berbagai cara digunakan oleh orang tua untuk menghukum anak-anak mereka. Banyak orang tua yang melakukan kesalahan karena lebih memfokuskan pada hukuman ketimbang perilaku buruk anak. Apabila orang tua menghukum anak lima sampai enam kali sehari untuk perilaku buruk yang sama, itu berarti bahwa hukuman yang orang tua berikan tidak berjalan dengan baik. 
Orang tua perlu memahami bahwa bukan hukuman yang paling penting, tetapi dampak buruk dari hukuman. Sebenarnya, hukuman harus dapat mengubah perilaku buruk anak. Kalau tidak bisa, ganti dengan hukuman yang lain. Hukuman memang memiliki konsekuensi negatif. Namun jika digunakan secara tepat, hukuman bisa mengurangi atau bahkan menghilangkan perilaku buruk anak. Hanya saja, pemberian hukuman secara benar itu yang sulit. Perlu konsistensi yang terus menerus. Meskipun demikian, terlalu banyak hukuman juga tidak baik. Sebab, hal ini bisa menciptakan perasaan yang tidak menyenangkan. Kebanyakan orang tua percaya bahwa menghukum perilaku buruk akan menghentikan anak mengulangi perbuatannya. tertekan.

Menurut pengamatan peneliti selama mengamati sekitar lingkungan tempat tinggal peneliti yaitu di Kota Pematang Siantar peneliti melihat masih banyak orang tua yang menyelesaikan permasalahan anak dengan memberikan hukuman. Salah satu yang paling sering dilakukan adalah memberikan hukuman fisik. Orang tua yang memberikan hukuman disebabkan oleh rendahnya pengetahuan orang tua tentang memberikan hukuman. Selain itu, masih banyak juga orang tua yang memberikan hukuman karena tradisi turun temurun, serta menjadikan anak sesuai dengan keinginan orang tua. Secara khusus, permasalahan yang ditemukan dari observasi di lokasi penelitian adalah: (1) Rendahnya pengetahuan orang tua tentang hukuman fisik (kekerasan); (2) Orang tua masih menggunakan metode hukuman fisik (kekerasan) untuk mengupayakan anak meraih prestasi dalam belajar.

\section{Disiplin Belajar}

Ditinjau dari asal kata, kata disiplin berasal dari bahasa latin discere yang memiliki arti belajar. Dari kata ini kemudian muncul kata disciplina juga mengalami perkembangan makna. Kata disiplin sekarang ini dimaknai secara beragam. Ada yang mengartikan disiplin sebagai kepatuhan terhadap peraturan atau tunduk pada Pengawasan dan pengendalian. Ada juga yang mengartikan disiplin sebagai latihan yang bertujuan mengembangkan diri agar dapat berperilaku tertib (Ratri, 2012:142). Berdasarkan beberapa batasan di atas, disiplin belajar dapat peneliti artikan posisi (kecenderungan) suatu sikap mental untuk mematuhi aturan, tata tertib, dan sekaligus mengendalikan diri, menyesuaikan diri terhadap aturan-aturan yang berasal dari luar sekalipun yang mengekang dan menunjukkan kesadaran akan tanggung jawab terhadap tugas dan kewajiban. Novi (2015:121) mengemukakan beberapa bentuk disiplin, yaitu: Pertama, Disiplin Otoriter Bentuk disiplin otoriter ini adalah bentuk disiplin tradisional yang berdasar pada ungkapan kuno, yaitu "Menghemat cambukan berarti memanjakan 
anak". Kedua, disiplin yang Lemah. Bentuk disiplin model ini biasanya timbul dan berkembang sebagai kelanjutan dari disiplin otoriter yang dialami orang dewasa saat ia masih anak-anak. Karena orang tua sudah pernah menjalani disiplin otoriter ketika masih kecil, mereka mendidik anaknya dengan cara yang sangat berlawanan. Menurut metode disiplin ini, anak akan belajar bagaimana berprilaku dari setiap akibat perbuatannya itu sendiri. Ketiga, disiplin Demokratis. Bentuk disiplin model ini menekankan pada hak anak untuk mengetahui kenapa sebuah aturan dibuat dan ia memperoleh kesempatan untuk mengemukakan pendapatnya sendiri bila menganggap bahwa peraturan itu tidak adil. Dengan demikian, disiplin belajar dapat diartikan posisi (kecenderungan) suatu sikap mental untuk mematuhi aturan, tata tertib, dan sekaligus mengendalikan diri, menyesuaikan diri terhadap aturan-aturan yang berasal dari luar sekalipun yang mengekang dan menunjukkan kesadaran akan tanggung jawab terhadap tugas dan kewaji.

\section{Hukuman}

Berdasarklan bahasa asalnya, kata hukuman berasal dari bahasa Inggris, yaitu dari kata punishment yang berarti hukuman (law) atau siksaan. Sedangkan menurut istilah, hukuman memiliki banyak makna. Hukuman (punishment) sering dimaknai sebagai usaha edukatif yang digunakan untuk memperbaiki dan mengarahkan anak ke arah yang benar, bukan praktik hukuman dan siksaan yang memasung kreativitas (Yanuar, 2012:15).

Hukuman (punishment) yang berarti menjatuhkan hukuman kepada seseorang karena suatu kesalahan, perlawanan, atau pelanggaran ini disengaja, dalam arti bahwa orang itu mengetahui bahwa perbuatan itu salah tetapi tetap saja melakukannya. Banyak orangtua melakukan hukuman yang berupa kekerasan yakni ingin anaknya disiplin, supaya menuruti apa kata orang tua, supaya anaknya jera, paling parah lagi karena prestasi dan disiplin. Sebagian orang tua menganggap hukuman dalam mengasuh dan mendidik anak itu adalah sebuah kewajaran dengan alasan hal itu telah dilakukan turun temurun.

Berdasarkan uraian pada latar belakang dan identifikasi masalah tersebut, maka penelitian bertujuan mengeksplorasi hukuman yang diberikan oleh orang tua baik hukuman langsung maupun tidak langsung terhadap anak usia 7-15 tahun di Kelurahan Tanjung Tongah Kota Pematang Siantar. Adapun yang menjadi rumusan permasalahan dalam penelitian ini adalah: apakah terdapat pengaruh pemberian hukuman yang diberikan oleh orang tua terhadap disiplin belajar anak usia 7-15 tahun di Kelurahan 
Tanjung Tongah Kota Pematang Siantar?” Penelitian ini bermanfaat bagi masyarakat di Kelurahan Tanjung Tongah Kota Pematang Siantar untuk memperbaiki cara menghukum anak. Selain itu, penelitian ini akan memberikan kontribusi pada kajian tentang pemberian hukuman pada anak. Sehingga nanti dapat menjadi bahan kajian berikutnya pada penelitian atau kajian tentang pendidikan pada anak.

\section{METODE PENELITIAN}

Penelitian ini dilaksanakan di Kelurahan Tanjung Tongah Kota Pematang Siantar. Berdasarkan data yang diperoleh, diketahui bahwa lokasi ini memiliki penduduk sebanyak 425 Jiwa. Alasan peneliti mengambil lokasi ini dikarenakan dari hasil pengamatan saya banyak orang tua yang ingin mendisiplinkan anak dengan cara pemberian hukuman, terutama dengan cara memukul dengan alasan lebih efektif kepada anak. Kelurahan Tanjung Tongah adalah salah satu kelurahan yang terletak di dalam wilayah kecamatan siantar Martoba.

Metode penelitian diartikan sebagai cara ilmiah untuk mendapatkan data dengan tujuan dan kegunaan tertentu (Sugiono, 2014:3). Dalam penelitian ini penulis menggunakan pendekatan deskriptif kuantitatif. Penelitian deskriptif adalah penelitian yang dimaksudkan bertujuan menyelidiki keadaan, kondisi atau hal lain-lain yang sudah disebutkan, yang hasilnya dipaparkan dalam bentuk laporan penelitian (Arikunto, 2010:3). Sesuai dengan pendapat Sugiyono (2014: 117) maka populasi adalah wilayah generalisasi yang terdiri atas: obyek/subyek yang mempunyai kualitas dan karakteristik tertentu yang ditetapkan oleh peneliti untuk dipelajari dan kemudian ditarik kesimpulannya.

Populasi bukan hanya orang, tetapi juga obyek dan benda alam-benda alam yang lain. Populasi juga bukan sekedar jumlah yang ada pada objek/subjek yang dipelajari, tetapi meliputi seluruh karakteristik/sifat yang dimiliki oleh subjek atau objek itu. Sedangkan, sampel adalah bagian dari jumlah dan karakteristik yang dimiliki oleh populasi tersebut. Pengambilan sampel dilakukan menggunakan Sampling Purposive. Sampling Purposive (Sugiyono, 2015:124) adalah teknik penentuan sampel dengan pertimbangan tertentu. Jadi sampel diambil berdasarkan pertimbangan/kriteria tertentu. Kriteria sampel adalah keluarga yang memiliki anak berusia 7-15 tahun.

Validitas dan Reabilitas Angket

Suatu instrument dikatakan valid atau sah jika instrument tersebut mampu mengukur apa yang semestinya diukur. Pengujian validitas disini menggunakan 
pengujuan validitas konstrak (Construct Validity). Dimana untuk menguji validitas kontrak, dapat digunakan pendapat dari ahli (Judgement Experts) (Sugiyono, 2014:176).

Statistik yang digunakan dalam pengujian validitas ini, adalah koefisien korelasi antar skor test sebagai prediktor dan skor suatu kriteria yang relevan. Dan uji coba akan dilakukan di daerah Kelurahan Pondok Sayur Kota Pematang Siantar dengan kriteria yang sama dengan sampel yaitu keluarga yang mempunyai anak usia 7-15 tahun dan pernah mendapatkan hukuman fisik dari orang tua nya. Untuk pengujian ini dilakukan dengan menggunakan statistik product moment. Uji Reabilitas adalah kemantapan/ keterandalan/ keajegan suatu alat pengukur, sehingga jika alat tersebut digunakan selalu memberikan hasil yang konsisten. Untuk mencari reabilitas dalam penelitian ini ditentukan dengan menentukan Alpha Cronbach dari Angket.

\section{HASIL PENELITIAN DAN PEMBAHASAN}

Berdasarkan temuan di lapangan dan selanjutnya dilakukan olah data dengan rumus yang telah di tetapkan, didapati oleh hasil skor rata-rata keseluruhan indikator pada variabel pembinaan $(\mathrm{X})$ adalah sebesar 2,81 yang telah dikonsultasikan dengan skala nilai di atas maka dapat disimpulkan hal ini menunjukkan bahwa pemberian hukuman yang dilakukan termasuk dalam kategori baik. Secara khusus pemberian hukuman tersebut adalah sebagai berikut:

\section{a. Pemberian Hukuman dengan cara Menjewer}

Untuk mengetahui keadaaan indikator manajemen dengan cara memukul, berikut adalah hasil sekor rata rata dari indikator tersebut:

Tabel

Hasil rata-rata skor indikator menjewer

\begin{tabular}{|c|c|c|}
\hline No Item & Nilai Rata-Rata & Kategori \\
\hline 1 & 3 & Baik \\
\hline 2 & 2,88 & Baik \\
\hline 3 & 2,94 & Baik \\
\hline Rata-rata keseluruhan & 2,94 & Baik \\
\hline
\end{tabular}

Berdasarkan nilai rata-rata indikator memukul diperoleh skor sebesar 2,94 dapat dikategorikan bahwa indikator memukul pada pemberian hukuman terhadap disiplin belajar anak baik. Indikator memukul dikategorikan baik karena orang tua memukul anaknya ketika anaknya tidak mau belajar dan ketika terlalu bebas bergaul, ini dapat meningkatkan disiplin belajar anak. 


\section{b. Indikator Memarahi}

Untuk mengetahui keadaan indikator melempar, berikut adalah skor rata-rata dari indikator tersebut :

Tabel

Hasil rata-rata skor memarahi

\begin{tabular}{|c|c|c|}
\hline No Item & Nilai Rata-Rata & Kategori \\
\hline 4 & 2,91 & Baik \\
\hline 5 & 2,91 & Baik \\
\hline 7 & 2,66 & Baik \\
\hline Rata-rata Keseluruhan & 2,82 & Baik \\
\hline
\end{tabular}

c. Indikator Menyuruh mengerjakan pekerjaan rumah

Untuk mengetahui keadaan indikator mencubit berikut adalah skor rata-rata dari indikator tersebut:

Tabel

Hasil Skor Rata-Rata Menyuruh mengerjakan pekerjaan rumah

\begin{tabular}{|c|c|c|}
\hline No Item & Nilai Rata-Rata & Kategori \\
\hline 8 & 2,66 & Baik \\
\hline 10 & 2,91 & Baik \\
\hline 11 & 3,25 & Baik \\
\hline 12 & 2,72 & Baik \\
\hline Rata-rata Keseluruhan & 2,88 & Baik \\
\hline
\end{tabular}

Berdasarkan nilai rata-rata mencubit diproleh skor sebesar 2,88 sehingga dikategorikan bahwa indikator mencubit dikategorikan baik. Indikator mencubit dikategorikan baik karena orang tua mencubit anak-anaknya ketika tidak mendengarkan perkataan orang tua, dan supaya anak-anak tidak melakukan kesalahannya lagi.

\section{c. Indikator Mencubit}

Untuk mengetahui indikator menampar berikut adalah skor rata rata dari indikator tersebut :

Berdasarkan tabel pengaruh pemberian hukuman diatas terlihat bahwa pemberian hukuman terbagi dalam 8 indikator, dan sesuai dengan konsultasinya dengan skala nilai, maka masing masing indikator dikategorikan baik. Untuk lebih jelas lagi, data dari pengaruh pemberian hukuman diatas dapat digambarkan menggunakan grafik batang sebagai berikut : 


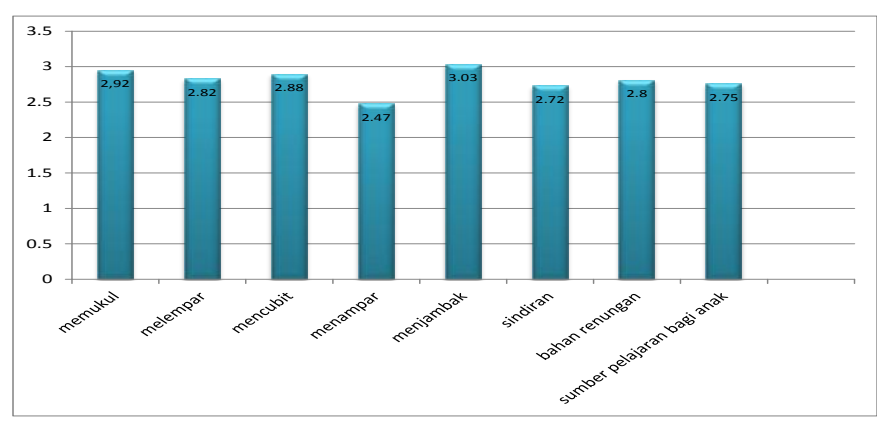

( Gambar Diagram Indikator Pemberian Hukuman Pada Anak)

Melalui gambar di atas terlihat bahwa Pemberian hukuman terbagi dalam 8 indikator. Grafik pemberian hukuman dari orang tua tersebut memiliki skor rata-rata tertinggi adalah 3,03 yaitu indikator menjambak, selanjutnya 2,94 yaitu indikator memukul, 2,88 indikator mencubit, selanjutnya dengan nilai yang sama 2,8 yaitu melempar dan bahan renungan, 2,75 indikator sumber pelajaran bagi anak, 2,72 indikator sindiran serta 2,47 indikator menampar. Maka ke delapan indikator tersebut dapat dikatakan baik.

Tabel

Rekapitulasi Skor Rata-Rata Disiplin Belajar Anak

\begin{tabular}{|l|l|c|c|}
\hline No & Indikator & $\begin{array}{c}\text { Nilai Rata- } \\
\text { Rata }\end{array}$ & Kategori \\
\hline 1 & Ketegasan dalam menegakkan peraturan & 2,70 & Baik \\
\hline 2 & $\begin{array}{l}\text { Mengingatkan anak untuk melakukan } \\
\text { rutinitas biasa yang selalu dilakukan }\end{array}$ & 2,63 & Baik \\
\hline 3 & $\begin{array}{l}\text { Tidak menuntut anak sesuai dengan } \\
\text { keinginan pribadi }\end{array}$ & 2,68 & Baik \\
\hline 4 & $\begin{array}{l}\text { Orang tua harus memiliki tekad yang sama } \\
\text { ketika membuat aturan disiplin }\end{array}$ & 2,22 & Baik \\
\hline 5 & $\begin{array}{l}\text { Aturan yang dibuat dengan anak } \\
\text { berasaskan demokrasi }\end{array}$ & 2,32 & \\
\hline
\end{tabular}

Tabel kemandirian usaha mikro menunjukkan kemandirian usaha mikro terbagi dalam 5 indikator. Semua indikator dikategorikan baik, yang aling tingi yaitu ketegasan dalam menegakkan peraturan yaitu: 2, 70. Untuk lebih jelas data dari tebel kemandirian berwirausaha di atas dapat digambarkan dalam bentuk grafik sebagai berikut :

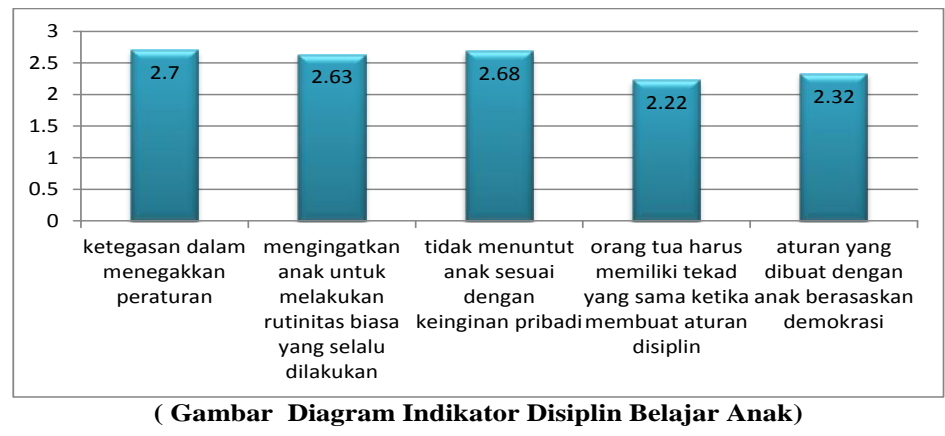




\section{Regresi Linier Sederhana}

Untuk mengetahui apakah terdapat pengaruh antara pemberian hukuman terhadap disiplin belajar anak dalam penelitian ini dilakukan dengan menggunakan regresi linier sederhana. Analisis digunakan untuk memprediksi nilai variabel independen mengalami kenaikkan atau penurunaan. Dari hasil perhitungan diketahui persamaan regresinya adalah $\hat{Y}=17,612+0,726$ X. Dengan memperhatikan persamaan tersebut, maka diketahui ada pengaruh pemberian hukuman terhadap disiplin belajar anak di Kelurahan Tanjung Tongah Kota Pematang Siantar.

\section{Hipotesis}

Uji hipotesis dilakukan setelah diketahui terlebih dahulu hasil perhitungan besar koefisien korelasi variabel X terhadap Y. Koefisien korelasi tersebut diuji signifikannya dengan uji t. Koefisien korelasi pengaruh pemberian hukuman dari orang tua terhadap disiplin belajar anak dari hasil perhitungan diketahui ada korelasi yang positif $\left(\mathrm{r}_{\text {hitung }}=\right.$ $0,719)$ antara pemberian hukuman dari orang tua $(\mathrm{X})$ terhadap disiplin belajar anak $(\mathrm{Y})$, berarti semakin baik pemebrian hukuman yang dilakukan orang tua semakin baik pula tingkat disiplin belajar anak di Kelurahan Tanjung Tongah Kota Pematang Siantar. Untuk mengetahui apakah pemberian hukuman dari orang tua memiliki pengaruh yang signifikan terhadap disiplin belajar anak di Kelurahan Tanjung Tongah Kota Pematang Siantar, maka dilakukan pengujian dengan rumus uji $\mathrm{t}$ dan hasil dari perhitungan diperoleh nilai $t_{\text {hitung }}>t_{\text {tabel }} 8,677>1,698$. Sedangkan besarnya konstribusi disiplin belajar anak terhadap pemberian hukuman dari orang tua dapat dilihat melalui perhitungan determinan diperoleh nilai $\mathrm{D}=51,7 \%$, artinya bahwa meningkat atau menurunya disiplin belajar di Kelurahan Tanjung Tongah Kota Pematang Siantar sebesar $51,7 \%$ dipengaruhi oleh pemberian hukaman dari orang tua sedangkan sisanya $48,3 \%$ disebabkan faktor lain yang tidak termasuk dalam analisis ini.

Hukuman (punishment) yang berarti menjatuhkan hukuman kepada seseorang karena suatu kesalahan, perlawanan, atau pelanggaran ini disengaja, dalam arti bahwa orang itu mengetahui bahwa perbuatan itu salah tetapi tetap saja melakukannya. Hukuman merupakan suatu perbuatan yang secara sadar dan sengaja menjatuhkan nestapa kepada orang lain, baik dari segi jasmani maupun rohani. Tujuan jangka pendek dari pemberian hukuman adalah untuk mengehentikan tingkah laku yang salah. Sedangkan tujuan jangka panjangnya adalah untuk mengajarkan dan mendorong pelakunya untuk menghentikan sendiri tingkah laku yang salah tersebut (Bunda Novi, 2015:66). 
Hukuman juga berfungsi sebagai penangkal, juga mengandung makna pensucian dari dosa dan kepalsuan hati. Pensucian itu akan berarti dengan syarat mau berhenti dari berbuat dosa, dan konsisten meninggalkannya. Karena hukuman pada dasarnya bukanlah cobaan, melainkan sarana pembinaan (M Nabil Kazhim, 2008:44). Jadi bisa peneliti simpulkan bahwa hukuman diartikan sebagai penderitaan yang diberikan atau ditimbulkan dengan sengaja oleh seseorang (orang tua, guru, dsb) setelah terjadi suatu pelanggaran, kejahatan, kesalahan.

Kemudian Hukuman represif yaitu hukuman yang dilakukan karena adanya pelanggaran dan kesalahan. Sifat dari hukuman represif adalah menekan atau menghambat. Sehingga, seorang anak yang sudah terlanjur melakukan suatu kesalahan akan merasa jera untuk melakukan kesalahan serupa dimasa mendatang. Pendapat lain menyatakan bahwa hukuman represif dilakukan untuk menyadarkan anak agar ia kembali melakukan hal-hal yang benar, yakni hal-hal yang tidak bertentangan dengan aturan-aturan yang ada atau yang telah disepakati bersama. Dengan diterapkannya hukuman preventif dan represif ini disiplin belajar anak cukup baik di Kelurahan Tanjung Tongah Kota Pematang Siantar dimana anak-anak selalu mengikuti peraturan dan takut melanggar aturan dari orang tua.

Untuk menguji keberartian koefisien korelasi diperoleh dengan menggunakan uji $\mathrm{t}$ hasil dari perhitungan diketahui taraf signifikansi $5 \%$ dan $\mathrm{dk}=\mathrm{n}-2$ yaitu $35-2=33$, maka diperoleh $t_{\text {hitung }}>t_{\text {tabel }}$ yaitu 8,677 >1,698. Maka $H_{o}$ ditolak dan $H_{a}$ diterima artinya pemberian hukuman yang dilakukan orang tua memiliki pengaruh di Kelurahan Tanjung Tongah Kota Pematang Siantar. Berdasarkan perhitungan tersebut, dapat dilihat bahwa terdapat pengaruh yang signifikan antara pemberian hukuman yang dilakukan orang tua terhadap disiplin belajar anak di Kelurahan Tangjung Tongah Kota Pematang Siantar.

\section{PENUTUP}

Berdasarkan hasil dari pembahasan diatas, dapat ditarik kesimpulan sebagai berikut: (1) Pemberian hukuman pada anak-anak di Kelurahan Tanjung Tongah Kota Pematang Siantar menerapkan hukman langsung dan tidak langsung, yaitu dimana hukuman langsung yang diberikan kepada anak-anak yaitu berupa memukul, mencubit, menampar kepada anak apabila anak tidak menurut apa yang dikatakan orang tua, hal ini bertujuan untuk mendisiplinkan anak suoaya taat pada peraturan dan disiplin dalam belajar, kemudian juga orang tua menerapkan hukuman secara tidak langsung kepada anak yaitu berupa sindiran, bahan renungan bagi anak, dan nasihat kepada anak supaya 
anak mengerti dan menaati peraturan yang dibuat orang; (2) Disiplin Belajar Anak di Kelurahan Tanjung Tongah Kota Pematang Siantar dalam kategori cukup baik. Dimana anak-anak tersebut punya keinginan untuk belajar dan patuh terhadap orang tua karena takut akan hukuman yang diberikan orang tua.

\section{DAFTAR PUSTAKA}

Arikunto, S. (2010). Prosedur Penelitian Suatu Pendekatan Praktik. Jakarta: Rineka Cipta.

Gramedia, Kompas. (2015). Mengasuh dan Mendidik Buah Hati Tanpa Kekerasan. Jakarta: Gramedia.

Gaza, M. (2012). Bijak Menghukum Siswa. Jogjakarta:Ar-Russ.

Kompas.com. (2012). Memukul picu gangguan emosi anak. diakses dari http://health.kompas.com pada 12 januari 2017

Media K. R. R. (2012). Character Building. Jogjakarta: Ar-Russ Media.

Novi, B. (2015). Saat Anak Harus Diberi Hadiah Atau Hukuman. Jogjakarta: Saufa

Yanuar, A. (2012). Jenis-Jenis Hukuman Edukatifn Untuk Anak SD. Jogjakarta: Diva Press.

Kazim, M. N. (2010). Mendidik anak tanpa kekerasan. Jakarta: Pustaka Al Kautsar.

Shoehib, M. (2010). Pola Asuh Orang Tua Dalam Membantu Anak Mengembangkan Disiplin Diri. Jakarta: Rineka Cipta.

Slameto. (2010). Belajar dan Faktor yang mempengaruhinya. Jakarta: Rineka Cipta.

Siregar, E. \& Nara, H. (2010). Teori Belajar dan Pembelajaran. Bogor: Ghalia Indonesia

Sudjana, S. (2001). Metoda Statistika. Bandung: PT Tarsito.

Sugiarti, G. (2015). Evaluasi dan Penilaian Hasil Belajar Kimia. Medan: Unimed Press. Sugiyono, S. (2008). Metode Penelitian Pendidikan. Bandung: Alfabeta.

Syah, M. (2012). Psikologi Belajar. Jakarta: Rajawali

Unicef (2015). Kekerasan terhadap anak: Kini Saatnya Bertindak. diakses dari https://www.unicef.org. pada diakses 22 Febuari 2017

Unicef. (2013). Stop kekerasan terhadap anak merupakan urusan semuaorang. Diakses dari https://www.unicef.org pada 1 Maret 2017 
Windari, R. (2015). Penggunaan Hukuman Disiplin (Corporal Punishment) pada Anak di lingkungan Sekolah dalam Perspektif Hukum Pidana. Jurnal Hukum Prioris, 4(3), 303-328. 